\title{
The inhibitory efficacy of flavonoid of mangosteen peel extract (Garcinia mangostana Linn.) against Lactobacillus Acidophilus biofilm bacteria
}

\author{
Dyah Utari Wahyu Ningrum ${ }^{1}$, Karlina Samadi ${ }^{2}$, Widya Saraswati ${ }^{2}$ \\ ${ }^{1}$ Student of Dental Medicine \\ ${ }^{2}$ Teaching Staff of Dental Medicine \\ Faculty of Dental Medicine, Universitas Airlangga \\ Surabaya - Indonesia
}

\begin{abstract}
Background: Lactobacillus takes role in the formation of dental plaque which is the main factor that cause dental caries. The bacteria take role in the metabolism of glucose in the mouth, producing organic acids which lower the pH in the oral cavity. This situation can lead to the formation of dental caries because these bacteria can form biofilm as a defense of microorganisms to antibiotics and the immune response. Mangosteen peel has active ingredients such as flavonoid that can be used to inhibit biofilm. The ability of flavonoid compounds in the phenol group can make the bacterial enzyme becomes inactive, causing the activity of glucosyltransferase enzyme that usually used by bacteria to synthesize sucrose in the medium becomes glucan. As a result, bacterial biofilm formation is inhibited because the amount of glucan as a medium of bacterial attachment is limited, but until now the effectivity dose of flavonoid from mangosteen peel extract (Garcinia mangostana Linn.) is has not known yet Purpose: The aim of this study was to determine the inhibitory efficacy of flavonoid of mangosteen peel extract against the formation of Lactobacillus acidophilus bacterial biofilm. Methods: Bacteria that had been formed into biofilms was studied in two times treatment, one concentration reviewed by flavonoid from mangosteen peel extract and without reviewed by flavonoid from mangosteen peel extract. The treatment group was incubated at $37^{\circ} \mathrm{C}$ until day 8 since the first day incubated. The treatment group was washed with phosphate buffered saline (PBS) 4 times and dried. The treatment group stained with $0.2 \mathrm{ml} 0.1 \%$ crystal violet and 15 min incubation. The treatment group was rinsed with distilled water 3 times and then dried. Solvent DMSO 100\% was added as much as 0.1 $\mathrm{ml}$ in each well. Microtiter plate was shaken for 1 minute and then placed in to the microplate reader and then the OD (Optical Density) can be read. Results: There were significant differences between the inhibitory efficacy of flavonoid of mangosteen peel extract against Lactobacillus acidophilus biofilm bacteria, the control group and group treatments (p $<0.05)$. Conclusion: Flavonoid of mangosteen peel extract with the concentration of $0.78 \%$ had inhibitory effect against Lactobacillus acidophilus biofilm bacteria.
\end{abstract}

Keywords: Mangosteen peel extract; Garcinia mangostana Linn.; Flavonoid; Lactobacillus acidophilus biofilm bacteria; caries.

Correspondence: Dyah Utari Wahyu Ningrum, Student of Dental Medicine, Faculty of Dental Medicine, Universitas Airlangga. J1. Prof. Dr. Moestopo 47 Surabaya 60132, Indonesia. Email: dyahutariwn@gmail.com

\section{INTRODUCTION}

Caries is the process of demineralizing hard tooth tissue due to bacterial metabolic activity. The occurrence of caries involves vulnerable hosts, caries-causing bacteria, and a substrate for bacteria. Caries-causing bacteria include Streptococci, Lactobacilli, and Actinomycetes ${ }^{1}$. Although Streptococcus mutans is now considered the dominant bacterium for caries initiation, some bacteria in plaque biofilms also participate in the development of carious lesions, namely Streptococci (Streptococcus salivarius, Streptococcus angreocus), Lactobacilli (Lactobacillus acidophilus, Lactobacillus casei), and Actinomycetes (Actinomyces viscosus, and Actinomyces naeslundii) ${ }^{2}$. These organisms produce organic acids, especially lactic acid, by fermenting carbohydrates on the tooth surface. A decrease in $\mathrm{pH}$ to below 5.5 results in demineralization of the surface of the tooth and then a formation of small holes called dental caries ${ }^{3}$. The basic character of a carious lesion is to develop from the surface of the tooth, either enamel or cementum then progress to dentin and finally the pulp ${ }^{2}$. Human oral cavity never free of bacteria ${ }^{4}$. Dental plaque is a tooth deposit formed on the surface of the tooth that is almost entirely composed of bacteria that originate from the 
normal flora of the mouth ${ }^{2}$. Clinically plaque is a structured, soft and greyish yellow substance that is firmly attached to the hard surface in in the oral cavity including removable or fixed restoration ${ }^{5}$.

Lactobacillus is very instrumental in the formation of dental plaque which is a major factor causing dental caries $^{6}$. Lactobacillus species are gram-positive bacteria that are not sporadic with bacillus-shaped cells (rods) and are facultative anaerobes found in the mouth, stomach, intestine, and genitourinary tractus ${ }^{7}$. Lactobacillus is often an agent for secondary caries lesions that can accelerate the demineralization of tooth surfaces ${ }^{1}$. Lactobacillus acidophilus produces lactic acid as the final product of carbohydrate fermentation. These bacteria play a role in glucose metabolism in the mouth by producing organic acids which reduce the $\mathrm{pH}$ in the mouth to less than ${ }^{5}$. This low $\mathrm{pH}$ will cause decalcification and the beginning of tooth decay ${ }^{3}$. This can cause the formation of dental caries because these bacteria can form biofilms as defence of microorganisms against antibiotics and immune responses ${ }^{8}$.

Biofilm is a kind of microbial aggregate or different types attached to the surface of biological and non-biological substrates, where one cell with other cells is bound and attached to the substrate by means of an extracellular polymeric substance (EPS) matrix ${ }^{9}$. The formation of biofilms is a bacterial defence mechanism. The process of biofilm formation starts from the initial attachment stage, the permanent attachment stage, maturation I, maturation II, and the dispersion stage. In the initial attachment stage, the microbes attach to the surface of solid objects with the intermediary Fili (fine hair). Then proceed with the permanent sticking stage, the microbes sticking further with the help of extracellular polymeric substance (EPS). At the maturation stage I, there is a withdrawal in other bacteria to form extracellular polysaccharides and bacterial cells continue to grow and develop. Then proceed the maturation stage II. At this stage, the accumulated bacteria form several layers. Then proceed with the final stage of the dispersion stage, that is, some bacteria will spread and colonize elsewhere ${ }^{10}$. Bacteria in the form of biofilms show higher resistance to antimicrobials compared to the free planktonic form. Influencing factors include the presence of extracellular matrix polymer physically limiting the diffusion of antimicrobial agents, the presence of resistance factors, such as drug-activating enzymes. For example, $\beta$-lactamase causes the degradation of $\beta$-lactam antibiotics. Therefore, the retention of enzymes in biofilms enhances the function of the barrier ${ }^{11}$. Biofilm bacteria make it possible to survive in a low nutrient environment in the root canal by using mangosteen skin flavonoids ${ }^{12}$.

Mangosteen (Garcinia mangostana Linn.) Is one of Indonesia's original fruit plants that has a huge export potential. This plant is nicknamed queen of fruit (queen of fruit) because of its privileges and delicacy ${ }^{13}$. Mangosteen holds a variety of extraordinary benefits for health or commonly referred to as functional food (functional food). Mangosteen market potential and opportunity is very large because of the large global demand. The benefits of this mangosteen fruit in the country itself is not yet known by the public. Mangosteen which has enough potential, is currently managed very simply. Mangosteen has long been used as a drug and therapeutic material, especially the skin part ${ }^{14}$.

Several types of fruit have been used as energy sources, but income has not met expectations. Mangosteen is one of them. So far, most people only judge mangosteen from one side only. People only enjoy the taste of mangosteen fruit, without them knowing that mangosteen peel contains substances that are beneficial to the body such as antioxidants, antibacterial, anti-inflammatory, anticarcinogenic and antiproliferation ${ }^{15}$.

During this time the use of mangosteen rind (Garcinia mangostana Linn.) In Indonesia for tanning leather, as a colouring agent for food and the textile industry. While the yellow sap is used as raw material for paints and insecticides, besides that the mangosteen rind boiled water has an anti-diarrhea effect. Though there are other compounds contained in mangosteen peel, namely xanthones which include mangosteen, mangosterol, mangostinon $\mathrm{A}$ and $\mathrm{B}$, trapezifolixanthone, tovophyllin $\mathrm{B}$, alpha and beta mangosteen, garcinon B, mangostanol, epicatinine flavonoids, and gartanin ${ }^{16}$. Some active components of the skin of the skin mangosteen fruit that can be used as a biofilm inhibits one of them is flavonoids.

Flavonoids are secondary metabolites which are found in green plants, except for algae. Flavonoids commonly found in higher plants (Angiosperms) are flavones and flavonoids with $\mathrm{C}$ - and $\mathrm{O}$-glycosides, isoflavones $\mathrm{C}$ - and $\mathrm{O}$-glycosides, flavanone $\mathrm{C}$ - and O-glycosides, chalcons with $\mathrm{C}$ - and $\mathrm{O}$-glycosides and dihydrochhalone, proanthocyanidin and anthocyanin, auron O-glycosides and dihydroflavonol O-glycosides. The flavone, flavonol, flavanon, isoflavone, and chalcon groups are also often found in the form of the aglycone.

In biofilms, flavonoids work by interfering with the interaction between acyl-homoserine lactones (AHLs) and their receptors so that quorum sensing bacteria or bacterial signalling will be disrupted. AHLs are signalling molecules in bacteria that play a role in the formation of biofilms ${ }^{17}$. In addition, the ability of flavonoid compounds in the phenol group makes bacterial enzymes inactive, causing the activity of glucosyltransferase enzymes that bacteria use to synthesize sucrose in the media into glucans. As a result, the formation of biofilms is hampered because the amounts of glucans as a medium for attachment of bacteria is small or limited ${ }^{18}$. According to Lee Jin-Hyung et al 2011, previous studies have been conducted on the ability of flavonoids to inhibit the formation of biofilms of Streptococcus mutans, Aeromonas hydrophila, and Escherichia coli.

Based on previous research, it does not rule out the possibility that the content of flavonoid compounds which are phenol derivatives in mangosteen rind (Garcinia mangostana Linn.) can inhibit the growth of Lactobacillus acidophilus so that research on the inhibitory power of flavonoid mangosteen peel on the formation of Lactobacillus acidophilus bacterial biofilms can be carried out. 


\section{MATERIALS AND METHODS}

This research is a type of experimental laboratory research. The study was conducted at the Tropical Infection Disease Hospital, Surabaya. The research sample was the bacterial biofilm Lactobacillus acidophilus which was bred using brain heart infusion broth (BHIB). There are 9 groups where group I was manipulated without using flavonoids as a control group, group II was manipulated with mangosteen peel extract flavonoids with 100\% flavonoids, group III was modulated with flavonoid mangosteen peel extract $50 \%$ concentration, group IV was modulated with flavonoid mangosteen peel extract concentration of $25 \%$, group V was mixed with mangosteen peel extract flavonoid concentration $12.5 \%$, group VI was mixed with mangosteen peel extract flavonoid concentration $6.25 \%$, group VII was treated with flavonoid mangosteen peel extract concentration 3.125\%, group VIII was modulated with flavonoid mangosteen peel extract concentration $6.25 \%$, group VII was regulated with flavonoid mangosteen peel extract concentration $3.125 \%$, group VIII was modulated with flavonoid mangosteen peel extract concentration $6.25 \%$, group VII IX was mixed with mangosteen peel extract flavonoids with a concentration of $0.78 \%$.

96 wells flat-bottom plate microtiter, Reaction Tubes, Plate, Eppendorf Micropipette, INB 500 Memmert Incubator, iMark Microplate Reader S / N 12096, Inverted IX 51 Olympus Microscope, Olympus BX 53 teaching microscope, Autoclaft, Vortex mixer, Nephelometry / turbidimetry, Scales, Name tags, Rotary evaporators. Soy Broth Trypticase (TSB), Lactobacillus acidophilus bacterial culture, Flavonoid mangosteen peel extract, Aquadest, Simple staining (crystal violet), 100\% DMSO, 96\% ethanol solution, Phosphate Buffer Saline (PBS), McFarland Kit.

Preparation of the initial suspension of Lactobacillus acidophilus bacteria with a turbidity of $0.5 \mathrm{McF}$ arland or

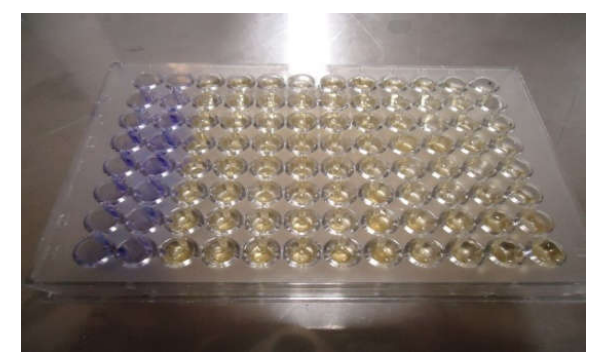

Figure 1. Microtiter plate that has been conducted biofilm inhibition effect test and will be read the OD with microplate reader. equivalent to $1.5 \times 106 \mathrm{CFU} / \mathrm{ml}$. Dilution of bacterial colonies by dilution method to a concentration of $108 \mathrm{CFU}$ $/ \mathrm{ml}$ in the test tube. $1 \mathrm{ml}$ of bacteria was taken and placed on each microtiter plate with TSB media and incubated for $7 \times 24$ hours and then labelled. The suspension was cultured for 7 days at $37^{\circ} \mathrm{C}$ and checked the formation of biofilms using an inverted microscope. Biofilm verification by simple staining (crystal violet) staining was then observed with a teaching microscope.

The treatment is given test material and without test material. Incubated at $37^{\circ} \mathrm{C}$ until the 8th day since the first incubation. Washed with phosphate buffer saline (PBS) 4 times and dried. The staining process with $0.1 \%$ crystal violet as much as $0.2 \mathrm{ml}$, incubated 15 minutes. Rinse with distilled water 3 times and then dried. $0.1 \mathrm{ml}$ of $100 \%$ DMSO solvent was added to each well. Microtiter plate shake for 1 minute then place it on the microplate reader.

\section{RESULTS}

This study used Lactobacillus acidophilus bacteria which was inserted into a microtiter plate with TSB media and incubated at $37^{\circ} \mathrm{C}$ for $7 \times 24$ hours to form a biofilm which was then given a mangosteen skin flavonoid extract to see whether there was an inhibitory effect of the material on the Lactobacillus acidophilus biofilm. The concentration of mangosteen peel extract flavonoids used in this study were $100 \%, 50 \%, 25 \%, 12.5 \%, 6.25 \%, 3.125 \%, 1.56 \%$ and $0.78 \%$ with positive control and negative control. Each concentration was repeated 3 times.

$$
\text { Viability }=\frac{\text { OD value of treatment group }}{\text { OD value of control group }} \times 100 \%
$$

From the OD reading, eight concentrations showed lower OD values than control OD values. At a concentration

Table 2. Kruskal-Wallis test results

\begin{tabular}{cccc}
\hline Concentration & $\mathrm{N}$ & Mean Rank \\
\hline & $0.78 \%$ & 3 & 2.67 \\
$1.56 \%$ & 3 & 8.17 \\
$\mathrm{OD}$ & $3.125 \%$ & 3 & 8.83 \\
& $6.25 \%$ & 3 & 11.17 \\
& $12.5 \%$ & 3 & 11.83 \\
& $25 \%$ & 3 & 22.00 \\
& $50 \%$ & 3 & 18.00 \\
$100 \%$ & 3 & 17.33 \\
\hline
\end{tabular}

Table 1. Measurement results microplate reader OD biofilm bacteria Lactobacillus acidophilus

\begin{tabular}{lccccccccc}
\hline & \multicolumn{7}{c}{ Extract Concentration } \\
\cline { 2 - 8 } & $100 \%$ & $50 \%$ & $25 \%$ & $12.5 \%$ & $6.25 \%$ & $3.125 \%$ & $1.56 \%$ & $0.78 \%$ & $0 \%$ (positive control) \\
\hline \multirow{3}{*}{ OD biofilm value } & 0.083 & 0.041 & 0.049 & 0.037 & 0.045 & 0.036 & 0.027 & 0.026 & 0.110 \\
& 0.035 & 0.044 & 0.054 & 0.033 & 0.030 & 0.030 & 0.025 & 0.021 & 0.168 \\
Mean & 0.038 & 0.039 & 0.057 & 0.032 & 0.026 & 0.026 & 0.037 & 0.019 & 0.103 \\
OD Percentage & 0.052 & 0.041 & 0.053 & 0.034 & 0.032 & 0.031 & 0.030 & 0.022 & 0.127 \\
\hline
\end{tabular}


of $0.78 \%$ to $100 \%$ the Lactobacillus acidophilus bacterial biofilm still grows well at a concentration of $0.78 \%$, which means that at that concentration mangosteen skin flavonoids are able to damage the biofilm by $82.68 \%$ of the number of bacteria that have successfully grown on positive control. At concentrations of $6.25 \%$ and $12.5 \%$ there is a percentage of OD with the same value, it is because of the possibility of improper selection, process and extraction methods so that the value of OD percentage does not change.

Based on the above table, there are differences in all groups. From the statistical calculations with the KruskalWallis Test, a significance level of 0.000 is obtained, which means it is smaller than $0.05(\mathrm{p}<0.05)$. This shows that there are significant differences between the concentration groups. Then proceed with the Mann-Whitney test to determine the differences in each concentration group.

Followed by the Mann-Whitney Test to find out the differences in each treatment group. From the statistical calculations using the Mann-Whitney Test between the concentration groups and the control group, $\mathrm{p}$ values were less than $0.05(\mathrm{p}<0.05)$ and $\mathrm{p}$ greater than $0.05(\mathrm{p}<0.05)$, which showed that there were Significant differences between the two concentration groups on the control group.

\section{DISCUSSION}

Caries is the process of demineralizing hard tooth tissue due to bacterial metabolic activity. The occurrence of caries involves vulnerable hosts, caries-causing bacteria, and a substrate for bacteria. Lactobacillus is very instrumental in the formation of dental plaque which is a major factor causing dental caries ${ }^{6}$. Lactobacillus is often an agent for secondary caries that can accelerate the demineralization of tooth surfaces ${ }^{1}$. The formation of biofilms is one of the defense mechanisms of a collection of bacteria. Bacteria in the form of biofilms are one of the adaptive processes that allow bacteria to survive in a low nutrient environment in the root canal ${ }^{12}$.

Mangosteen (Garcinia mangostana Linn) is a fruit that has been proven to have many health benefits such as mouth ulcer drugs, hemorrhoids, and wounds. Mangosteen rind contains several active components that can be used as an antibiofilm, one of which is flavonoids. Flavonoid is a polar compound which is generally easily dissolved in polar solvents such as ethanol, methanol, butanol and acetone. Flavonoids are the largest group of phenol compounds which have effective properties to inhibit the growth of viruses, bacteria and fungi.

Laboratory experimental research on the bacterial biofilm of Lactobacillus acidophilus was carried out in vitro using the Microtiter Plate Assay method with a modification of $^{22}$. The study obtained a value that is Optical Density (OD) biofilms measured using ELISA reader. This study was conducted to determine the ability of the inhibitory effect of mangosteen skin flavonoids at certain concentrations on the bacterial biofilm of Lactobacillus acidophilus, because the same research had never been done before. Mangosteen peel extract is isolated so that the flavonoid compounds are separated. Where flavonoids have been shown to have antibacterial and antibiofilm properties.

In this study, mangosteen peel extract flavonoids were used with various concentrations, namely $100 \%, 50 \%$, $25 \%, 12.5 \%, 6.25 \%, 3.125 \%, 1.56 \%$, and $0.78 \%$ with the aim to see ability to inhibit the growth of mangosteen skin flavonoids. Replication at each concentration was carried out 3 times. And the results obtained in the form of OD (Optical Density) values are not consistent at several concentrations. The percentage of biofilm growth is calculated using the formula. At a concentration of $0.78 \%$ to $25 \%$, there was a decrease in the percentage of inhibition. Then experience an increase in the percentage of inhibition at a concentration of $50 \%$ to a concentration of $100 \%$.

In this study, the concentration group of $0.78 \%$ to $12.5 \%$ concentration showed an average getting bigger, this is because the higher the concentration given, the less biofilm was inhibited. But in the concentration group of $25 \% 50 \%$ and $100 \%$, the mean values were getting smaller, this was due to the high flavonoid density of mangosteen peel extract, resulting in a disturbance in the reading of OD.

The statistical analysis data shows that the results obtained are not homogeneous because it can be caused by differences in time variables when preparing samples, one of which is when mixing the test material and Lactobacillus acidophilus biofilms. It is possible that between one well another there is an interval of a few seconds during the mixing process. In addition, an error during incubation can also result in varied results. Then it can also be caused by the washing procedure of each well before the optical density value is seen on a different microplate reader. Different washing results where one sample is cleaner than the other will also produce different absorbance readings on the microplate reader. Cleaner washing will facilitate light when penetrating the test material and results in greater absorbance and lower optical density values.

In practice, there are difficulties in getting results that meet the requirements to be read on the microplate reader. The difficulty is the extract used has a turbid character, thick and dark in color so that the reading results become difficult. Because the reading of the OD value uses the absorption of colors from the suspension being read. Thus, at higher concentrations, it is possible to obtain lower OD values than higher OD values.

Other possible factors that influence the inconsistent percentage inhibition value are the possibility of improper selection, extraction processes and methods, extraction results that are so turbid, concentrated and dark in color, and the process of conducting research that is less thorough in terms of time, procedures, appropriateness of tool use and materials during the study, and for a concentration of $25 \%$ with a small percentage of inhibition, there is a possibility of contamination so that the test material does not work well.

From these eight repetitions, the results obtained showed that all concentrations could inhibit the formation 
of biofilms produced by Lactobacillus acidophilus bacteria, because bacterial OD biofilms treated with extracts were always lower than OD of bacterial biofilms that were not given extracts (positive control). This is consistent with the theory that a material that has antibiofilm power can damage biofilms in various ways, including by penetrating the extracellular matrix, dispersing cells from biofilms, or eliminating the stability of EPS on biofilms ${ }^{23}$.

The results of the study showed that there were significant differences in accordance with existing theories. Mangosteen skin flavonoids are proven to be antibiofilm. Based on the theory, flavonoids have the ability to damage the bacterial cell membrane through the destruction of the lipid layer on the bacterial membrane and cause the barrier cell membrane function to be disrupted. Flavonoid activity causes damage to bacterial cell membranes, so that there will be a decrease in the function of the bacterial membrane barrier and intramembrane leakage. This causes bacterial aggregation to decrease so that bacterial colonies that form on the surface will also decrease ${ }^{19}$. Flavonoids also disrupt the activity of cell signaling by decreasing $\alpha$-hemolysin which is a bacterial exotoxin and resulting in permanent adhesion and formation of colonies on the tooth surface is inhibited ${ }^{24}$.

Regarding the inhibition of biofilms, the ability of flavonoid compounds in the phenol group to inactivate bacterial enzymes causes the activity of the glucosyltransferase enzyme used by bacteria to synthesize sucrose in the media into glucans (EPS). As a result, the formation of biofilms is inhibited because the amount of glucan as a medium for attachment of bacteria is small or limited. This can indicate that the flavonoid compounds in phenols can inhibit the formation of biofilms in bacteria ${ }^{18}$.

From this research it is hoped that further research will be carried out using methods other than calculating OD values so as to find a better way to inhibit the growth of the Lactobacillus acidophilus bacterial biofilm. From the results of the study, it can be concluded that the mangosteen peel extract flavonoids have inhibitory properties against the formation of Lactobacillus acidophilus bacterial biofilms.

\section{REFERENCES}

1. Quivey, R.G., 2006, Caries, dalam Oral Microbiology and Immunology, diedit oleh Lamont, R.J., Burne, R.A., Lantz, M.S., Leblanc, D.J ASM Press, Washington, h. 233-52.

2. Ryan KJ, Ray CG. 2004. Sherris Medical Microbiology (4th ed.). McGraw Hill.

3. Sharma S, Webb R, Macpherson D, Wilson A. 2008. Severe Tissue Necrosis Following Intra-arterial Injection of Endodontic Calcium Hydroxide: A Case Series. Oral Surg Oral Med Oral Pathol Oral Radio Endodontics; 105(5): p. 666-9

4. Wilson TG, Kornman KS. Fundamentals of Periodontics, Second Edition. Hong Kong: Quintesence Publishing Co Inc, 2003: 491-3.

5. Newman MG, Takei HH, Klokkevold PR, Carranza FA. 2012. Carranza's Clinical Periodontology. $11^{\text {th }}$ ed. Missouri: Saundres: p: 243-245.
6. Badet, C., dan Thebaud, N.B 2008. Ecology of Lactobacilli in the Oral Cavity: AReview of Literature. Op KHMro J. (2): 38-48.

7. Murray, P.R., Baron, E.J., Jorgensen, J.H., Pfaller, M.A., Yolken, R.H., 2003, Manual of Clinical Microbiology, 8 Ed., ASM Press, Washington DC, p.407, 409, 411, 413-5.

8. Noguchi N, Noiri Y, Narimatsu M, Ebisu S. Identification and Localization of Extradicular Biofilm-Forming Bacteria Associated with Refractory Endodontic Pathogens. Applied and Environmetal Microbiology 2005; 71(12). pp: 8738-43.

9. Hall-Stoodley, L, J.W. Costerton, P. Stoodley. 2004. Bacterial biofilms: from the natural world to infectious disease. Nat. Rev. Microbial. 2(2). Pp 95-108.

10. Maier, Raina et a. 2009. Environmental Microbiology. 2009. USA: Academic press of Elsevier.

11. Hojo, K. 2009. Bacterial Interactions in Dental Biofilm Development. J Dent Res88(11): p. 982-990.

12. Shrestha, A. 2010. Nanoparticulates for Antibiofilm Treatment and Effect of Aging on Its Antibacterial Activity. J Endod. Vol. 36: p. 1030-1035

13. Anonim. 2010. Kulit Buah Manggis Dapat Menjadi Minuman Instan Kaya Antioksidan. Warta Penelitian dan Pengembangan, Volume 32, Nomor 2, Hal. 5-6.

14. Permana, A.W. 2010. Kulit Buah Manggis dapat Menjadi Minuman Instan Kaya Antioksidan. Warta Litbang Deptan 32(2): 3 hal.

15. Weecharangsan W, Opanasopit P, Sukma M, Ngawhirunpat T, Sotanaphun U, dan Siripong P. 2006. Antioxidative and neuroprotective activities of extract from the fruit hull of mangosteen (Garcinia mangostana Linn.) Med Princ Pract. 15(4): 281-287.

16. Iswari, T. R, 2007. Buku Pegangan Ilmu Pengetahuan Kosmetik. Penerbit Gramedia Pustaka Utama, Jakarta. Halaman 6-8.

17. Manner S, Malena Skogman, Darla Goeres, Pia Vuorela and Adyary Fallareo. 2013. Systemic Exploration of Natural and Synthetic Flavonoids for the Inhibition of Staphylococcus aureus Biofilms. International Journal of Molecular Sciences pp. 19434-51.

18. Ardina, Marisya, Pratiwi, Sylvia, Hertina, Triana. 2010. Efek Campuran Minyak Atsiri Daun Cengkeh Dan Kulit Batang Kayu Manis Sebagai Anti Plak Gigi. MajalahFarmasi Indonesia 21(3). pp: 191-201.

19. Cushnie TP, Lamb J. 2005. Review antimicrobial Activity of flavonoids. IJAA. V1. 26, p. 343.

20. Agustrina G. 2011. Apitherapy-A sweet approach to dental diseases. Part II: Propolis. Journal of Academy of Advanced Dental Research. Vol. 2, No. 6, p.3.

21. Anggraini DN. 2006. Potensi propolis lebah muda Apismelifera sp. Sebagai Bahan Antibakteri. Departemen Biokimia Fakultas Matematika dan Ilmu Pengetahuan Alam Institut Pertanian Bogor. H.3.

22. Merritt, Judith H., Daniel E. Kadouri, George A. O'Toole. 2011. Growing and Analyzing Static Biofilm. Current Protocol in Microbiology 22:1B.1.1-1B.1.18.

23. Bueno J. 2014.Anti-Biofilm Drug Susceptibility Testing Methods: Looking for New Strategies against Resistance Mechanism. J Microbial BiochemTechnol S3: 004. doi:10.4172/1948-5948.S3-004.

24. Cheung AL and G. Zhang. 2002. Global regulation of virulence determinants in Staphylococcus aureus by the SarA protein family. Frontiers in Bioscience, vol. 7, pp. d1825d1842, 2002. 